\title{
PERSEPSI PEMUDA TERHADAP PEMILIHAN UMUM LEGISLATIF PADA TAHUN 2019 DI KECAMATAN MILA KABUPATEN PIDIE
}

\author{
Zulfikar $^{1}$, Nasrul $^{2}$ \\ Program Studi Ilmu Administrasi Fakultas Ilmu Administrasi \\ Zulfikarmila1990@gmail.com
}

\begin{abstract}
ABSTRAK
Demokrasi adalah ide cemerlang yang mengubah perpolitikan dunia.Munculnya Demokrasi merupakan gagasan politik mengandung nilai-nilai yang sangat dibutuhkan sebagai acuan untuk menata kehidupan berbangsa didalam suatu negara.Dalam pemilu, warga negara dapat memberi hak suaranya baik berupa hak pilih maupun hak untuk tidak memilih. Sebagai proses dan kualitas kehidupan demokrasi di negeri ini,Dukungan seluruh rakyat terhadap pemilu adalah kewajiban masyarakat dalam bernegara untuk menentukan bangsa yang lebih maju.Pemilu bukan saja untuk memilih wakil-wakil rakyat dan atau pemimpin nasional yang berlegitimasi, tetapi juga karena pemilu itu sendiri secara substansial membawa pesan moral agar rakyat memilih wakil-wakil rakyat yang memiliki hati nurani.Berdasarkan uraian diatas maka peneliti dapat merumuskan masalah sebagai berikut: 1)Bagaimana taggapan pemuda terhadap pemilihan umum legislatif pada tahun 2019? 2)Bagaimana tingkat kesadaran pemuda tarhadap pemilihan umum legislatif pada tahun 2019?

Pendekatan yang digunakan dalam penelitian ini adalah pendekatan kuantitatif dengan jenis deskriptif. Pendekatan kuantitatif dengan jenis deskriptif bertujuan untuk menjelaskan, meringkaskan berbagai kondisi, berbagai situasi, atau berbagai variabel yang timbul di masyarakat yang menjadi objek itu berdasarkan apa yang terjadi.

Dari hasil penelitian ditemukan berbagai macam gejolak dan tingkah laku para pemilih dan calon legislatif untuk meraup suara, pada tahun 2019 ini terdapat lebih dari setengah pemuda di kecamatan mila memilih calon legislatifsebesar 53\% dan kurang dari setengah $47 \%$ pemuda tidak menggunakan hak pilihnya. Inilah yang menjadi tolak ukur di kalangan pemuda begitu apatis terhadap politik yang berjalan dinegeri ini. Kekecewaan yang pemuda dapatkan dari anggota legislatif terdahulu dimana janji-janji yang di ingkari dan harapan-harapan yang sirna bagaikan di telan bumi dan yang lebih mirisnya lagi dari 53\% pemuda hampir sebahagian dari mereka memilih dengan faktor keuangan dan dorongan orang lain dan sangat sedikit yang memilih sesuai dengan hati nurani,

Atas dasar itulah mereka memilih untuk tidak terlibat dalam pemilihan umum legislatif pada tahun ini, dan lebih memilih untuk bekerja dan melakukan hal lain yang lebih bermamfaat bagi dirinya.
\end{abstract}

\section{PENDAHULUAN}

\section{Latar Belakang}

Demokrasi adalah ide cemerlang yang mengubah perpolitikan dunia.Munculnya demokrasi adalah suatu yang dianggap penting karena merupakan gagasan politik mengandung nilai-nilai yang sangat dibutuhkan sebagai acuan untuk menata kehidupan berbangsa didalam suatu negara.

Dalam pemilu, warga negara dapat memberi hak suaranya baik berupa hak pilih maupun hak untuk tidak memilih. Sebagai proses dan kualitas kehidupan demokrasi di negeri ini, pemilu legislatif patut mendapat 
dukungan oleh seluruh rakyat Indonesia. Bukan saja fungsi pemilu adalah untuk memilih wakil-wakil rakyat dan atau pemimpin nasional yang berlegitimasi, tetapi jugakarena pemilu itu sendiri secara substansial membawa pesan moral agar rakyat memilih wakil-wakil rakyat yang memiliki hati nurani.

Politik adalah sebuah teknik yang mengatur dan mengelola sebuah negara untuk suatu kebijakan sesuai perundang undangan yang ada.

Para pemuda akan memainkan peran yang sangat penting dalam bingkai politik di Tanah Air, khususnya pada pemilu yang digelar serentak dengan pemilihan presiden pada tahun 2019, pemilih berusia 17-30 tahun berjumlah $30 \%$ dari total pemilih.

Disadari atau tidak, pemuda sejatinya memiliki peran dan fungsi yang strategis dalam akselerasi pembangunan termasuk pula dalam proses kehidupan berbangsa dan berbegara. Pemuda yang kerap disebut sebagai harapan bangsa itu merupakan aktor dalam pembangunan

\section{Rumusan masalah}

Berdasarkan uraian diatas maka peneliti dapat merumuskan masalah sebagai berikut

1) Bagaimana taggapan pemuda terhadap pemilihan umum legislatifpada tahun 2019?

2) Bagaimana tingkat kesadaran pemuda tarhadap pemilihan umum legislatif pada tahun 2019?

\section{Tujuan masalah}

Berdasarkan perumusan masalah seperti yang telah diuraikan diatas, penulis dalam mengadakan penelitian memiliki tujuan sebagai berikut:

1) Untuk mengetahui tanggapan pemuda terhadap pemilihan umum legislatif pada tahun 2019.
2) Untuk mengetahui tingkat kesadaran pemuda tarhadap pemilihan umum legislatif pada tahun 2019 .

\section{TINJAUAN PUSTAKA \\ Persepsi}

Terdapat berbagai pengertian tentang persepsi. Persepsi dapat diartikan sebagai sudut pandang atau cara pandang seseorang terhadap suatu objek. Persepsi seseorang akan memberi pengaruh terhadap proses pengambilan keputusan. Apabila persepsi seseorang baik atau positif terhadap suatu hal, maka pengambilan keputusan pun akan selaras dengan persepsi tersebut ataupun sebaliknya.

Menurut Davidoff yang dikutip olehWalgito (2010:89) bahwa yaitu Persepsi merupakan aktivitas yang intergrated dalam diriindividu akan ikut aktif dalam persepsi. Berdasarkan hal tersebut maka dalam persepsi dapat dikemukakan karena perasaan, kemampuan berfikir, pengalamanpengalaman individu tidak sama, hasil persepsi mungkin akan berbeda antara individu satu dengan individulain.

Menurut slameto (2010:102) persepsi adalah proses menyangkut masuknya pesan atau informasi kedalam otak manusia, melalui persepsi manusi terus menerus mengadakan hubungan dengan lingkungan.

\section{Pengertian Pemuda}

Pemuda adalah individu yang bila dilihat secara fisik sedang mengalami perkembangan dan secara psikis sedang mengalami perkembangan emosional, sehingga pemuda merupakan sumber daya manusia Pembangunan baik saat ini maupun nanti yang akan menggantikan generasi sebelumnya. Pemuda adalah individu dengan karakter yang dinamis, bahkan bergejolak dan optimis namun belum memiliki pengendalian emosi yang stabil.Pemuda menghadapimasa perubahan sosial maupun kultural. 
Menurut Mulyana (2011:5) pemuda adalah individu yang memiliki karakter dinamis,artinya memiliki karakter yang bergejolak, optimis dan belum mampu mengendalikan emosi yang stabil.

Menurut Undang-Undang Nomor 40 Tahun 2009 tentang kepemudaan pasal 1 ayat (1), mendefinisikan bahwa " Pemuda adalah warga negara Indonesia Yang memasuki periode penting pertumbuhan dan perkembangan yang berusia 16 (enam belas) sampai 30 (tiga puluh) tahun". Berdasarkan dari pengertian diatas maka dapat ditarik kesimpulan bahwa pemuda adalah mansuia yang berusia 16-30 tahun yang secara biologis telah menunjukan tanda-tanda kedewasaan.

\section{Definisi Pemilihan Umum}

Pemilu diselenggarakan dengan tujuan untuk memilih Anggota Dewan Perwakilan Rakyat, Dewan Perwakilan Daerah, dan Dewan Perwakilan Rakyat Daerah dan Pemilihan Umum adalah sarana pelaksanaan kedaulatan rakyat yang dilaksanakansecara langsung, umum, bebas, rahasia, jujur dan adil dalam Negara Kesatuan Republik Indonesia berdasarkan Pancasila dan Undang-undang Dasar Negara Republik Indonesia tahun 1945.

Menurut Tricahyo (2009:6) Secara universal Pemilihan Umum adalah instrumen mewujudkan kedaulatan rakyat yang bermaksud membentuk pemerintahan yang absah serta sarana mengartikulasikan aspirasi dan kepentingan rakyat.

Sedangkan menurut Haris(2006:10) Merupakan salah satu bentuk pendidikan politik Bagi rakyat,yang bersifat langsung, terbuka, massal, yang diharapkan bisa mencerdaskan pemahaman politik dan meningkatkan kesadaran masyarakat mengenai demokrasi.

\section{METODE PENELITIAN Pendekatan dan Jenis Penelitian}

Pendekatan yang digunakan dalam penelitian ini adalah pendekatan kuantitatif dengan jenis deskriptif. Sebagaimana yang dikemukakan oleh Bungin (2008:36) pendekatan kuantitatif dengan jenis deskriptif bertujuan untuk menjelaskan, meringkaskan berbagai kondisi, berbagai situasi, atau berbagai variabel yang timbul di masyarakat yang menjadi objek itu berdasarkan apa yang terjadi. Adapun tujuan dari penelitian ini yaitu untuk mengetahui tanggapan pemuda di kecamatan mila kabupaten pidie terhadap pemilihan umum legislatif padatahun 2019 dan didukung dengan studi perpustakaan untuk memperkuat analisis penelitian dalam membuat kesimpulan.

\section{Tempat dan Waktu Penelitian}

Pelaksanaan penelitian merupakan suatu tempat atau wilayah dimana penelitian akan dilakukan. Tempat penelitian yang akan dilaksanakan oleh peneliti bertempat di Kecamatan Mila kabupaten pidie.

\section{Populasi dan Sampel}

1) Populasi

Populasi adalah keseluruhan objek penelitian yang terdiri dari data yang dimilikikarakteristik tertentu dalam penelitian (Arikunto, 2010:73) yang menjadi populasi dalam penelitian ini adalah seluruh pemuda yang berada di kecamatan mila yaitu sebanyak 2000 orang

2) Sampel

Menurut Arikunto (2010:174) "Sampel adalah sebagian atau wakil populasi yang diteliti”. Adapun teknik pengambilan sampel yang digunakan untuk penelitian ini adalah sebanyak 100 orang yang mudah di temukan 


\section{Teknik Pengumpulan data}

Dalam memperoleh data yang dibutuhkan sebagai bahan pembuatan laporan penelitian, ada beberapa teknik / cara metode yang dilakukan oleh penulis sesuai dengan jenis penelitian kuantitatif. Selanjutnya dalam pengumpulan data yang berhubungan dengan masalah yang akan dibahas, penulis menggunakan tehnik yaitu:

1) Penelitian perpustakaan (library research) yaitu pengumpulan data yang dilakukan melalui perpustakaan untuk memperoleh sumber referensi baik

berupa buku-buku tes, skripsi, internet, dan bacaan lainnya.

2) Kuisioner adalah daftar pertanyaan atau pernyataan yang di buat untuk menggali informasi dengan mengajukan pertanyaan sesuai dengan kuisioner yang dinyatakan kepada beberapa responden. Sehingga mendapatkansejumlah Tanggapan dari pemuda terhadap pemilihan umum legislatif pada tahun 2019 di kecamatan milaKabupaten Pidie. dalam penelitian ini angket yang disebarkan berupa angket tertutup. Angket tertutup yang dimaksud dalam penelitian ini yaitu setiap pertanyaan yang di buat oleh peneliti telah disertai sejumlah pilihan jawaban. kemudian Responden hanya memilih jawaban yang paling sesuai.

\section{Teknik Pengelohan Data dan Analisis data} Menurut Bungin (2011:181), Pengolahan data statistik Pada dasarnya adalah proses pemberian kode (identitas) terhadap data penelitian melalui angka-angka pengolahan data yang dilakukan dalam penelitian ini menggunakan teknik analitif kualitatif (statistik sederhana) yaitu:

1. Menghitung jumlah frekuensi (F) dan setiap jawaban yang disediakan pada angket.
2. Menghitung presentase (P) dan setiap arternatif jawaban dengan rumus sebagai berikut:

$$
P=\frac{\mathrm{Fx}}{\mathrm{N}} \times 100 \%
$$

Keterangan:

$$
\begin{array}{ll}
\mathrm{P} & =\text { Persentase } \\
\mathrm{Fx} & =\text { Frekuensi individu } \\
\mathrm{N} & =\text { Jumlah Sampel }
\end{array}
$$$$
100 \% \text { = Bilangan Tetap }
$$

\section{Penelitian dan Pembahasan \\ Penelitian}

Tanggapan pemuda terhadap pemilihan umum legislatif pada tahun 2019.

Hasil penelitian yang akan diuraikan pada bab IV ini telah penulis laksanakan dengan judul "persepsi " berdasarkan data yang diperoleh dari penelitian ini penulis menggunakan metode kuantitatif. Dimana jawaban dari pertanyaan ditabelkan serta dijelaskan sesuai dengan jawaban responden.

Berdasarkan data yang diperoleh dari hasil penelitian, dapat dilihat pada tabel 1 Sampai tabel 20 berikut ini:

Untuk mengetahui pendapat responden mengenai Apakah Anda menggunakan hak pilih Anda saat pemilihan umum legislatif, dapat dilihat pada tabel 1 dibawah ini

Tabel 1. Untuk mengetahui tanggapan responden apakah menggunakan hak pilih saat pemilihan umum legislatif 2019.

\begin{tabular}{|l|l|l|l|}
\hline No & \multicolumn{1}{|c|}{$\begin{array}{c}\text { Alternatif } \\
\text { Jawaban }\end{array}$} & F & 0\% \\
\hline A & Ya & 63 & $63 \%$ \\
\hline B & Tidak & 37 & $37 \%$ \\
\hline & Jumlah (n) & 100 & $100 \%$ \\
\hline
\end{tabular}

Berdasarkan Tabel 1 diatas menunjukkan bahwa sebahagian besar $(63 \%)$ responden mengatakan menggunakan hak pilih saat pemilihan umum legislatif dan (37\%) Responden tidak mengunakan hak pilihnya saat pemilihan legislatif .Dari hasil 
tabel diatas maka dapat disimpulkan bahwa minat pemuda dalam menyalurkan hak pilihnya dalam pemilihan legislatif tahun 2019 lebih banyak dibandingkan dengan yang tidak menyalurkan hak pilihnya.

Untuk mengetahui Pendapat responden Apa alasan menggunakan hak pilih saat pemilihan umum legislatif, dapat dilihat pada tabel 2 berikut:

Tabel 2.Apa alasan menggunakan hak pilih saat pemilihan umum legislatif

\begin{tabular}{|c|l|l|l|}
\hline No & \multicolumn{1}{|c|}{ Alternatif Jawaban } & \multicolumn{1}{|c|}{ F } & \multicolumn{1}{|c|}{$0 \%$} \\
\hline A & Keinginan hati & 19 & $19 \%$ \\
\hline B & Dorongan orang lain & 26 & $26 \%$ \\
\hline C & Faktor keuangan & 18 & $18 \%$ \\
\hline D & Tidak memilih & 37 & $37 \%$ \\
\hline & Jumlah (n) & 100 & $100 \%$ \\
\hline
\end{tabular}

Berdasarkan Tabel 2 diatas menunjukkan bahwa sedikit sekali (19\%) responden mengatakan memilih legislatif berdasarkan keinginan hati dan sebahagian kecil $(26 \%)$ responden mengatakan memilih legislatif berdasarkan dorongan orang lain dan sedikit (18\%) responden mengatakan memilih legislatif berdasarkan faktor keuangan dan sebagian kecil (37\%) responden yang menjawab tidak memilih. Dari hasil tabel diatas peneliti dapat simpulkan bawah sebagian pemuda yang menyuarakan suaranya pada pemilihan leislatif adalah faktor keuangan.

Untuk mengetahui pendapat responden menurut Anda bagaimanakah kemampuan Calon anggota legislatif Kabupaten Pidie, dapat dilihat pada tabel 5 berikut:

Tabel 3.Bagaimanakah kemampuan Calon anggota legislatif Kabupaten Pidie,

\begin{tabular}{|c|l|l|l|}
\hline NO & Alternatif Jawaban & \multicolumn{1}{|c|}{ F } & \multicolumn{1}{|c|}{$0 \%$} \\
\hline A & Sangat mampu & 6 & $6 \%$ \\
\hline B & Mampu & 21 & $21 \%$ \\
\hline C & Tidak mampu & 35 & $35 \%$ \\
\hline D & Tidak tahu & 38 & $38 \%$ \\
\hline & Jumlah (n) & 100 & $100 \%$ \\
\hline
\end{tabular}

Dari tabel 5 diatas menunjukkan sedikit sekali (6\%) responden yang menyatakan calon anggota legislatif sangat mampu menjadi anggota dewan perwakilan daerah dan sebagian kecil (21\%) responden menyatakan mampu dan sebahagian kecil (27\%) responden mengatakan tidak mampu dan lebih dari setengah (54\%) responden mengatakan tidak tahu kemampuan calon anggota legislatif Kabupaten Pidie.

\section{Tingkat kesadaran pemuda tarhadap pemilihan umum legislatif pada tahun 2019}

Tingkat kesadaran pemuda terhadap pemilihan umum dapat di uraikan berdasarkan tabel di bawah ini

Untuk mengetahui pendapat responden mengenai Apakah anda menggunakan hak suara anda dalam pileg 2019 karena memiliki rasa kesadaran sebagai warganegara, dapat dilihat pada tabel 1 dibawah ini

Tabel 5. Untuk mengetahui Apakah responden menggunakan hak suara dalam pileg 2019 karena memiliki rasa kesadaran sebagai warganegara

\begin{tabular}{|c|l|l|l|}
\hline NO & \multicolumn{1}{|c|}{ Alternatif Jawaban } & F & $0 \%$ \\
\hline A & Ya & 41 & $41 \%$ \\
\hline B & Tidak & 59 & $59 \%$ \\
\hline & Jumlah (n) & 100 & $100 \%$ \\
\hline
\end{tabular}

Dari tabel di atas dapat dilihat bahwa kurang dari setengah pemudah (41\%)responden menggunakan hak suara dalam pileg 2019 karena memiliki rasa kesadaran sebagai warganegaradan lebih dari setengah (59\%) responden menggunakan hak suara dalam pileg 2019 karena memiliki rasa kesadaran sebagai warganegara.

Untuk mengetahui Apakah responden merasa masa bodoh terhadap Pileg dapat di lihat dari tabel di bawah ini 
Tabel 5.Apakah anda merasa masa bodoh terhadap Pileg

\begin{tabular}{|c|l|c|l|}
\hline NO & Alternatif Jawaban & F & \multicolumn{1}{|c|}{$0 \%$} \\
\hline A & Ya & 56 & $56 \%$ \\
\hline B & Tidak & 44 & $44 \%$ \\
\hline & Jumlah (n) & 100 & $100 \%$ \\
\hline
\end{tabular}

Dari tabel di atas dapat dilihat bahwa lebih dari setengah $(56 \%)$ merasa masa bodoh terhadap pileg dan kurang dari setengah (59\%) respondenresponden menggunakan hak suara dalam pileg 2019 karena memiliki rasa kesadaran sebagai warganegara.

\section{Pembahasan}

Dari hasil penelitian yang telah dilakukan oleh peneliti maka data yang diperoleh sebagai berikut.

Peran pemuda berperan aktif dalam kehidupan bermasyarakat dan bernegara, baik dari segi sosial, ekonomi, budaya, maupun politik. Keseriusan pemuda dalam politik yang baik demi kemajuan dalam mengembangkan ideologi negara Kualiatas pemuda ialah untuk perubahan yang akan di lakukan pada masa yang akan datang.

Kepedulian pemuda akan politik, nampaknya kian lama kian memudar. Hal ini bisa dilihat dari menurunnya persepsi pemuda dalam politik dan justru sebagian besar dari para pemuda sangat cenderung merasa apatis hal ini terbukti dari hasil penelitian yang dilakukan.

Pemahaman pemuda tentang pemilu harus ditingkatkan, terutama bagi pemuda pemilih pertama sangat penting dalam menyelenggarakan pemilihan memberikan hak pilihnya, pemilihan legislatif pemilih pemula hendaknya mengetahui visi, misi dan program bahkan riwayat hidup para calon legislatif yang akan dipilihnya. Dengan demikian, maka pemilih pemula akan miliki pertimbangan yang memadai sebelum memutuskan kemana suaranya akan diberikan.Setiap pemilu 40 persen dari total pemilih ialah milik pemuda namun terdapat sebanyak 37 persen dari pemuda tergolong tidak menyuarakan pilihannya dikarenakan pekerjaan ataupun tidak ada kepeduliannya terhadap politik.

Tingkat kesadaran pemuda memang tergolong sangat rendah dimana data yang penulis dapatkan dari hasil pembagian kuesioner beberapa pemuda yang datang memih merupakan pemuda yang mayoritas telah menerima pemberian uang dari calon kandidat maupun tim sukses sehingga mereka turut berpartisipasi dalam pemilihan.Mengapa pemuda tidak berperan aktif dalam politik karena faktor kegaduhan yang muncul di dunia politik yang sering di beritakan sehingga pemikiran pemuda mengangap politik selalu diwarnai dengan ketidak elokan dan ketidak harmonisan, dan selanjudnya terdapat masalah perilaku para aktor di panggung politik yang sering tidak sesui dengan janjinya pada saat kampaye.

Saat di analisis lebih lanjut kebanyakan pemuda menjawab banyak sekali konflik dan masalah yang ditimbulkan oleh politik dan janji janji yang tidak di tepati, sehingga mereka merasa politik ini seharusnya lebih baik dikesampingkan saja jika tidak ada satu pun yang bisa diambil. Atas dasar itulah mereka memilih untuk tidak terlibat dalam politik, dan lebih mengurusi hal yang lebih penting menurut mereka.

Dari hasil penelitian ditemukan 63\% pemuda menggunakan hak pilihnya dan dan $37 \%$ tidak mengunakan hak pilihnya. Inilah yang menjadi tolak ukur di kalangan pemuda yang begitu apatis terhadap politik yang berjalan dinegeri ini.

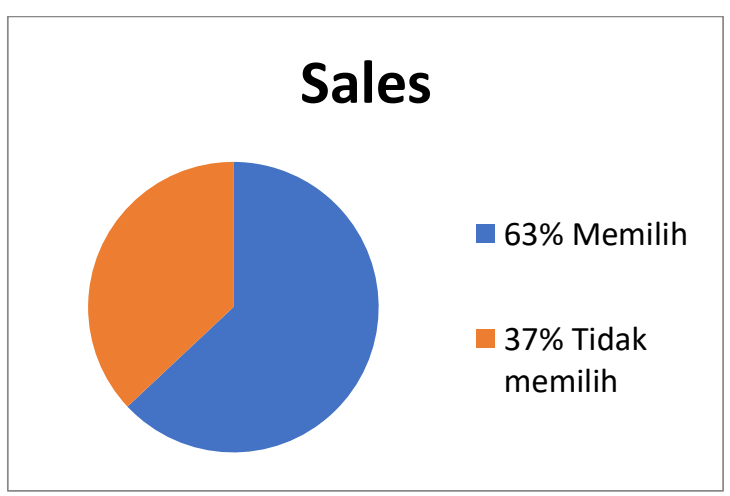


Adapun pemuda yang termasuk dalam golongan memilih hampir setengah dari mereka memilih dikarenakan faktor keungan dan dorongan dari orang laindan sangat sedikit yang memilih sesuai dengan hati nurani, walaupun kebanyakan dari merekan sering melihat dan mendengar kampaye dari berbagai calon anggota legislatif ketertarikan saat pemuda dalam menentukan pilihannya sangatlah minim dan bahkan kebanyakan antara merekan tidak mengetahui kemampuan calon yang diusung, dari paparan diatas dapat kita ketahui bahwa persepsi pemuda memang tergolong sangat rendah dikarenakan banyak sekali konflik dan masalah yang ditimbulkan oleh politik dan Kekecewaan yang pemuda dapatkan dari anggota legislatif terdahulu dimana janji-janji yang di ingkari dan harapan-harapan yang sirna bagaikan di telan bumi dan yang lebih mirisnya lagi dari $53 \%$ pemuda hampir sebahagian dari mereka memilih dengan faktor keuangan dan dorongan orang lain dan sangat sedikit yang memilih sesuai dengan hati nurani,.

Atas dasar itulah mereka memilih untuk tidak terlibat dalam pemilihan umum legislatif pada tahun ini, dan lebih mengurusi hal yang lebih penting menurut mereka.Dari hasil penelitian ditemukan berbagai macam gejolak dan tingkah laku para pemilih dan calon legislatif untuk meraup suara, pada tahun 2019 ini terdapat lebih dari setengah pemuda di kecamatan mila memilih calon legislatifsebesar $53 \%$ dan kurang dari setengah $47 \%$ pemuda tidak menggunakan hak pilihnya. Inilah yang menjadi tolak ukur di kalangan pemuda begitu apatis terhadap politik yang berjalan dinegeri ini.

Atas dasar itulah mereka memilih untuk tidak terlibat dalam pemilihan umum legislatif pada tahun ini, dan lebih memilih untuk bekerja atau melakukan hal lain yang lebih bermamfaat bagi dirinya.

\section{KESIMPULAN DAN SARAN \\ Kesimpulan}

Dari hasil penelitian yang telah dilakukan maka dapat di ambil kesimpulan bahwa

1) Kurang kepedulian pemuda terhadap terhadap pemilihan legislatif.

2) Lebih dari setengah pemuda memilih tidak berdasarkan hati nurani dan tidak berdasarkan kemampuan calon legislatif

3) Masih terdapat politik uang yang dimainkan oleh oknum canlon anggota legislatif

\section{Saran.}

1) Pemerintah harus memberi bimbingan kepada pem

2) uda agar lebih berperan dalam dunia politik.

3) Perlunya pengawasan ketat dari pihak yang berwenang terhadap politik uang yang dimainkan oleh oknum calon anggota legislatif.

\section{DAFTAR PUSTAKA}

Asrori, Mohammad. 2009. Psikologi Pembelajaran. Bandung: CV Wacana Prima

Matsumoto, David. 2008. Pengantar Psikologi Lintas Budaya. Pustaka Pelajar Yogyakarta.

Bimo, Walgito. 2010. Pengantar PsikologUmum. Yogyakarta: C.V Andi Offset.

Tricahyo, Ibnu,2009.Reformasi Pemilu Menuju Pemisahan Pemilu Nasional dan Lokal, Malang : In-Trans Publishing,.

Sumadiria, Haris. 2006. Jurnalistik Indonesia Menulis Berita dan Feature. Bandung: Simbiosa Rekatama Media. 
Jurnal Sains Riset (JSR)

ISSN 2088-0952

Bungin, M. Burhan. 2008. Penelitian Kualitatif. Jakarta: Kencana Prenada Media Group

Arikunto, Suharsimi. 2010. Prosedur Penelitian Suatu Pendekatan Praktik. Rineka Cipta : Yogyakarta.
Arikunto, S. (2013).Prosedur Penelitian: Suatu Pendekatan Praktik. Jakarta: Rineka Cipta.

Bungin, Burhan. 2011. Penelitian Kualitatif. Jakarta: Kencana Predana Media Group 